\title{
Review: Low Cost, Environmentally Friendly Humic Acid Coated Magnetite Nanoparticles (HA-MNP) and Its Application for the Remediation of Phosphate from Aqueous Media
}

\author{
Tadewos Damena, Tajeldin Alansi \\ Applied Chemistry Program, Adama Science and Technology University, Adama, Ethiopia \\ Email: tad.dam.keb2010@gmail.com, talansi@yahoo.com
}

How to cite this paper: Damena, T. and Alansi, T. (2018) Review: Low Cost, Environmentally Friendly Humic Acid Coated Magnetite Nanoparticles (HA-MNP) and Its Application for the Remediation of Phosphate from Aqueous Media. Journal of Encapsulation and Adsorption Sciences, 8, 256-279.

https://doi.org/10.4236/jeas.2018.84013

Received: October 4, 2018

Accepted: December 17, 2018

Published: December 20, 2018

Copyright $\odot 2018$ by authors and Scientific Research Publishing Inc. This work is licensed under the Creative Commons Attribution International License (CC BY 4.0).

http://creativecommons.org/licenses/by/4.0/

\begin{abstract}
Phosphate is a primary nutrient required for the normal functioning of many organisms in the ecosystem. However, presence of excess phosphate into the aquatic systems leads to eutrophication which can promote harmful algal growth and decrease the amount of dissolved oxygen in water. Municipal, industrial and agricultural run-off wastewaters are the major point sources for phosphate discharges. There are different methods to remove phosphates from water. Among these, adsorption is the most widely accepted method for phosphate removal because of its high efficiency, minimum cost, easy and simple operation and applicability at lower concentrations. The emphasis of this review, is to consolidate low cost, environmentally friendly humic acid coated magnetite nanoparticles (HA-MNP) and its application for the remediation of phosphate from aqueous media. The magnetic nanoparticles could be easily separated from the reaction mixture by using a simple hand held magnet and adsorption studies demonstrate the fast and effective separation of phosphate with maximum removal efficiency $>90 \%$ at $\mathrm{pH} 6.6$. The adsorption behavior follows the Freundlich isotherm and the removal of phosphate is found higher at acidic and neutral $\mathrm{pH}$ compared to basic conditions. The nanoparticles exhibit good selectivity and adsorption efficiency for phosphate in the presence of co-existing ions such as $\mathrm{Cl}^{-}, \mathrm{SO}_{4}^{2-}$ and $\mathrm{NO}_{3}^{-}$ with some inhibition effect by $\mathrm{CO}_{3}^{2-}$ and finally, the effect of temperature on the adsorption reveals that the process is endothermic and spontaneous.
\end{abstract}

\section{Keywords}

Phosphates, Magnetite Nanoparticle, Humic Acid \& Humic Acid Coated Magnetite Nanoparticle 


\section{Introduction}

Phosphorus is the mineral nutrient which is essential for all living species. It is one of the more understood nonrenewable available nutrients for fertilizers production [1]. Phosphate is a primary nutrient required for the normal functioning of many organisms in the ecosystem. However, the presence of trace amounts of phosphate (even below $1 \mathrm{mg} / \mathrm{L}$ ) in treated wastewater from municipalities and industries is often accountable for eutrophication which leads to short- and long-term environmental and esthetic problems in lakes, ponds, reservoirs, coastal areas, and other confined water bodies [2]. Nuisance algal blooms in eutrophic water bodies cause great negative consequences for ecosystem functioning and ecosystem services. In fact, eutrophication in relatively static water bodies has become a worldwide water quality issue. Among essential nutrients, phosphorus $(\mathrm{P})$ is widely recognized to regulate the algal blooms and to protect against nuisance in which average phosphorus concentration should not surpass $0.02 \mathrm{mg} / \mathrm{L}$ [3] [4]. Generally, the excessive presence of phosphorus in water bodies, which is mainly considered as a result of untreated sewage effluent and agricultural run-off, causes eutrophication problem which can promote harmful algal growth and decrease the amount of dissolved oxygen in rivers, lakes and seas. Eutrophication induces overgrowth of phytoplankton, thus deteriorating water quality, depopulating aquatic species and accelerating water scarcity. According to the Australian Water Quality Guidelines for Fresh and Marine Waters, the total phosphorus contaminant level in rivers and streams is controlled in the range of $0.010-0.100 \mathrm{mg} / \mathrm{L}$; whilst the requirement for lakes and reservoirs is more stringent as $0.005-0.050 \mathrm{mg} / \mathrm{L} \mathrm{[2]} \mathrm{[3]} \mathrm{[5]} \mathrm{[6].}$

Nowadays eutrophication has already become a globalized environmental problem in relatively stagnant water bodies and can cause comprehensive ecological crisis of aquatic environment, such as the decrease of biological diversity, the loss of landscape function and the potential health risk to human beings [7] [8]. Phosphorus is well recognized as the limiting factor for eutrophication. Thus, the removal of phosphate, the main species of phosphorus, from wastewater before discharge is one of the most effective ways for eutrophication control [9]. Adsorption is a promising technology for the removal of phosphate. Therefore, in recent years, investigations on adsorbents for immobilizing phosphate from water have been undertaken. As a consequence, phosphate removal, from wastewater has been considered as an important environmental sustainability concern [2]-[9].

\section{Methods of Phosphate Removal from West Water}

\section{1) Biological, Chemical, Physical and Adsorption Methods}

Phosphate removal from water has attracted considerable research interest in the last few decades. Until now, a range of methods have been developed, mainly including biological chemical and physical treatments [10] [11] [12] [13] [14]. Biological methods, i.e. the conventional activated sludge process, can achieve 
nearly $100 \%$ removal of phosphate. However, they are less effective at trace level, which is ascribed to the fact that the presence of insufficient phosphate lowers metabolism of microorganisms. Furthermore, specific care and strict control are often needed during implementation of biological methods [10] [11].

Chemical treatments using lime, alum, and iron salts have been mostly utilized in phosphate removal, which suffer difficulty in sludge disposal and effluent neutralization [10] [12]. Physical methods, as in the case of reverse osmosis and electro dialysis, have been proven to be either too expensive or inefficient in removal [13] [14]. In comparison to the aforementioned methods, the adsorption process is promising for phosphate removal attributed to its attractive advantages, which is simple operation, high removal efficiency and fast adsorption rate, especially at low phosphate concentration. In general adsorption is one of the most attractive approaches in water treatment, with the advantage of having high removal efficiency without yielding harmful bi-products [4]-[9].

It is well known that phosphates have a strong affinity for mineral surfaces. Its affinity for hydroxide surfaces depends on one hand on the anions' complexing capacity, which allows binding to surface groups by ligand exchange reactions, and on the other hand on electrostatic interactions with the charged hydroxide surfaces. The total annual economic cost for the process incorporated with chemical precipitation was approximately $10 \%$ lower than that with adsorption. However, the adsorption process could reduce phosphate concentration in the discharge to a much lower level, as compared with the chemical method [13] [14] [15]. The development of materials with superior adsorption capacity could further enhance phosphate removal, minimize sludge disposal and eventually make adsorption cost-effective for practical application [16]. Furthermore, the adsorption is able to be used for not only phosphate removal, but also phosphate recovery. In recent years, there has been tremendous interest focusing on the fabrication of mesoporous materials and their potential in different practical applications. Some review papers have been devoted to the fabrication of mesoporous materials and their use as adsorbents to remove ions, such as arsenate, chromate and molybdate [7] [8] [16] [17] [18] [19] [20]. Therefore, there is a wealth of literature on the study of $\mathrm{P}$-adsorbent for phosphate removal from water, as recently reviewed [17]-[23]. However, though a high affinity to adsorb $\mathrm{P}$ is a prerequisite as a good $\mathrm{P}$-adsorbent, additional aspects should also be taken into consideration for successful practical application. Among them, an adsorbent should be easily separated from water if one considers recycling the adsorbent material for repeated use, instead of onetime use.

\section{2) Magnetic Spinel Ferrites}

Magnetic spinel ferrites, which can be expressed as $\mathrm{M}\left(\mathrm{Fe}^{3+}\right)_{2} \mathrm{O}_{4}$ where $\mathrm{M}$ refers to a divalent metal ion such as $\mathrm{Fe}^{2+}, \mathrm{Mn}^{2+}, \mathrm{Co}^{2+}, \mathrm{Ni}^{2+}, \mathrm{Cu}^{2+}, \mathrm{Zn}^{2+}, \mathrm{Mg}^{2+}$, or $\mathrm{Cd}^{2+}$, etc., have the unique feature of superparamagnetism, hence, they can be easily separated from water by providing an external magnetic field. As ferrites are a kind of metal oxides, which are among the most investigated adsorbents for 
phosphate removal from water/wastewater, they can be expected to be adsorbents for $\mathrm{P}$ removal [17] [18]. Previous studies have investigated the adsorption of $\mathrm{P}$ by the ferrites of $\mathrm{Fe}_{3} \mathrm{O}_{4}, \mathrm{ZnFe}_{2} \mathrm{O}_{4}, \mathrm{CuFe}_{2} \mathrm{O}_{4}$ and $\mathrm{MnFe}_{2} \mathrm{O}_{4}$ and showed that they could be directly used for $P$ removal [20] [21] [22] [23]. Other studies indicated that, without modification, the affinity of ferrite materials for phosphate was still limited. Recently, different strategies have been investigated on ferrites to develop P-adsorption materials with both easy separability from water and improved phosphate adsorption performance [22] [23] [24] [34].

\section{3) Functionalization of Magnetic Materials}

In recent years, functionalization of magnetic materials with amine containing chemicals which have chelating ability was investigated to develop adsorbents for the removal of heavy metals. To date, ethylenediaminetetraacetic acid disodium salt (EDTA-Na), ethanediamine and triethylenetetramine were successfully functionalized on magnetic particles [25] [26]. It is considered that grafting an element that has high affinity for $\mathrm{P}$ onto the surface of ferrites would be efficient to fix $\mathrm{P}$, as the reactive sites with high adsorption affinity could contact more directly with $\mathrm{P}$ in solution. Owing to the high ability of binding phosphate through strong ligand coordination, the rare earth element lanthanum (La) has been successfully used to modify zeolite, bentonite, lignocellulosic materials and so on to develop highly efficient $P$ adsorbents [9] [27] [28].

Phosphate can be adsorb on iron oxides to form a variety of surface species, including mononuclear monodentate, mononuclear bidentate, and binuclear bidentate (Figure 1).

However, in most cases, iron oxides present slow adsorption kinetics owing to diffusion resistance and their separation from aqueous solutions after adsorption is difficult. Enhanced adsorption may be accomplished by reducing the iron oxides particles as nanoparticles. The equilibrium between phosphate ions in solution and solid surfaces may be altered by changing the concentration of phosphate ions in solution, the $\mathrm{pH}$ of the suspension, and other variables of less influence such as ionic strength and temperature [1] [29] [30] [31] [32].

\section{4) Nano-material Sciences}

In the present era of scarcity of water resources, effective treatment of wastewater is a major prerequisite for growing economy. It is critical to develop and implement advanced wastewater treatment technologies with high efficiency and low capital requirement. Among various treatments, recent advanced processes in nano-material sciences have been attracting the attention of scientists. This

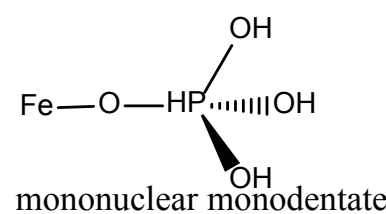

mononuclear monodentate

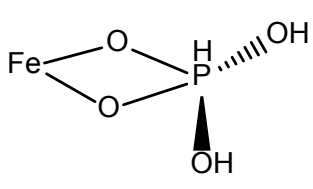

mononuclear bidentate

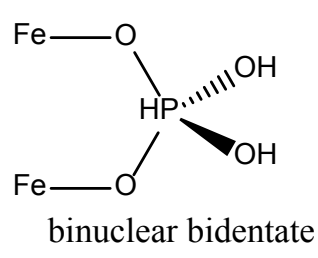

Figure 1. Possible configuration of the phosphate surface complexes. 
includes four main classes; First, nano-adsorbents such as activated carbon, carbon nanotubes, graphene, manganese oxide, zinc oxide, titanium oxide, magnesium oxide and ferric oxides that are usually applied for removal of heavy metals from the wastewater.

Second, nano-catalysts such as photocatalyst, electrocatalyst, Fenton based catalyst, and chemical oxidant have been shown the potential for removing both organic and inorganic contaminants. Third, nano membranes have been used for effective removal of dyes, heavy metals and foulants using carbon nanotube membranes, electrospun nanofibers and hybrid nano-membranes. Finally, the integration of nanotechnology with biological processes such as algal membrane bioreactor, anaerobic digestion microbial fuel cell and bio-chemically active materials found in soil such as humic acid were developed with respect to its potential for wastewater purification [33].

In recent years, iron based nanoparticles have been widely applied for environmental remediation as mentioned above. The strong magnetic property of such nanoparticles enables separation of adsorbent and adsorbate by using a simple magnet. Magnetite, an iron oxide $\left(\mathrm{Fe}_{3} \mathrm{O}_{4}\right)$ material shows the highest magnetism among all the naturally available minerals [34]. Application of bare magnetite nanoparticles (MNP) for the removal of toxic water contaminants have been reported in the literature (Table 1). However, the susceptibility to auto-oxidation, tendency to agglomerate and concerns over toxicity are the main challenges for the real life water treatment applications of bare MNP [32] [35]. The coating of natural organic matter (NOM) on the bare MNP surface has been

Table 1. Application of magnetite nanoparticles for the removal of pollutant from water.

\begin{tabular}{|c|c|c|c|c|c|c|}
\hline No. & Synthesis Method & Coating agents & $\begin{array}{c}\text { Surface } \\
\text { functionalized group }\end{array}$ & $\begin{array}{c}\text { Removal } \\
\text { efficiency (\%) }\end{array}$ & Metal removed & Ref. \\
\hline 1 & Thermolysis of precursors & Dimercaptosuccinic acid & Thiol group & - & $\begin{array}{l}\mathrm{Hg}(\mathrm{II}), \mathrm{Ag}(\mathrm{I}), \mathrm{Pb}(\mathrm{II}) \\
\quad \mathrm{Cd}(\mathrm{II}), \mathrm{Tl}(\mathrm{I})\end{array}$ & [58] \\
\hline 2 & Co-precipitation & Succinic acid & Carboxylic group & $\begin{array}{l}91 \mathrm{As}, \text { but } 100 \text { for } \\
\text { others. } \mathrm{pH}=8\end{array}$ & & \\
\hline 3 & Thermolysis of precursors & Ethylenediamine & Amine group & $\begin{array}{l}95 \text { As but } 100 \text { for } \\
\text { others } \mathrm{pH}=8\end{array}$ & $\begin{array}{c}\mathrm{Cr}(\mathrm{III}), \mathrm{Co}(\mathrm{II}), \mathrm{Ni}(\mathrm{II}), \\
\mathrm{Cu}(\mathrm{II}), \mathrm{Cd}(\mathrm{II}), \mathrm{Pb}(\mathrm{II}), \\
\mathrm{As}(\mathrm{III})\end{array}$ & [64] \\
\hline 4 & $\begin{array}{l}\text { Thermolysis of precursors followed } \\
\text { by ligand exchange process }\end{array}$ & Dimercaptosuccinic acid & Thiol group & $\begin{array}{l}97 \text { As but } 100 \text { for } \\
\text { others } \mathrm{pH}=8\end{array}$ & & \\
\hline \multirow{4}{*}{5} & \multirow{4}{*}{ Co-precipitation } & \multirow{4}{*}{ Humic acid } & \multirow{4}{*}{$\begin{array}{l}\text { Carboxylic and } \\
\text { phenolic group }\end{array}$} & $99, \mathrm{pH}=6.5-8.1$ & $\mathrm{Hg}(\mathrm{II}), \mathrm{Pb}(\mathrm{II})$ & \multirow{4}{*}{$\begin{array}{c}{[33][43]} \\
{[44][45]} \\
{[65]}\end{array}$} \\
\hline & & & & $95, \mathrm{pH}=6.5-8.1$ & $\mathrm{Cd}(\mathrm{II}), \mathrm{Cu}(\mathrm{II})$ & \\
\hline & & & & $98.5, \mathrm{pH}=2.53$ & Rhodamine B & \\
\hline & & & & $>90, \mathrm{pH}=6.6$ & Phosphate & \\
\hline 6 & Co-precipitation & $\begin{array}{l}\text { Carboxymethyl- } \beta \text { - } \\
\text { cyclodextrin }\end{array}$ & Carboxylic group & 96.2 & $\mathrm{Cu}(\mathrm{II})$ & [66] \\
\hline 7 & $\begin{array}{l}\text { Crystallization from ferrous } \\
\text { hydroxide gels }\end{array}$ & Polyethylenimine & Amine group & - & $\mathrm{Cu}(\mathrm{II})$ & [67] \\
\hline
\end{tabular}




\begin{tabular}{|c|c|c|c|c|c|c|}
\hline \multicolumn{7}{|c|}{ Continued } \\
\hline 8 & Co-precipitation & Dendrimers & Amine group & 90 & $\mathrm{Zn}(\mathrm{II})$ & [68] \\
\hline 9 & $\begin{array}{l}\text { Co-precipitation followed by a } \\
\text { sol-gel process using sodium } \\
\text { silicate }\left(\mathrm{Fe}_{3} \mathrm{O}_{4} @ \mathrm{SiO}_{2}\right)\end{array}$ & $\begin{array}{l}\text { (3-aminopropyl) } \\
\text { Trimethoxysilane }\end{array}$ & Amine group & - & $\mathrm{Pb}(\mathrm{II}), \mathrm{Cd}(\mathrm{II}), \mathrm{Cu}(\mathrm{II})$ & [69] \\
\hline 10 & $\begin{array}{l}\text { Stabilization of } \mathrm{Fe}^{0} \text { nanoparticles } \\
\text { with } \mathrm{Fe}_{3} \mathrm{O}_{4}\end{array}$ & - & - & 47.8 & $\mathrm{Cr}(\mathrm{VI})$ & {$[70]$} \\
\hline 11 & $\begin{array}{l}\text { Bacterial reduction of } \\
\text { schwertmannite }\end{array}$ & - & - & - & $\mathrm{Cr}(\mathrm{VI}), \mathrm{Tc}(\mathrm{VII})$ & [71] \\
\hline 12 & Co-precipitation & - & - & - & $\mathrm{As}(\mathrm{V})$ & {$[72]$} \\
\hline 13 & $\begin{array}{l}\text { Commercially available } \\
\text { magnetite-maghemite mixture } \\
\text { nanoparticles }\end{array}$ & - & - & 65 & $\mathrm{As}(\mathrm{V}), \mathrm{As}(\mathrm{III}), \mathrm{Cr}(\mathrm{VI})$ & [73] \\
\hline 14 & Commercially available Magnetite & - & - & 99 & $\operatorname{As}(\mathrm{V}), \mathrm{As}(\mathrm{III})$ & [74] \\
\hline 15 & $\begin{array}{l}\text { Modification of co-precipitation } \\
\text { method }\end{array}$ & Starch & Hydroxyl group & 91 & $\mathrm{As}(\mathrm{V})$ & {$[75]$} \\
\hline
\end{tabular}

found useful in making the nanoparticles less toxic and more environmental friendly. Such thin coatings can also inhibit the agglomeration and auto-oxidation, which are the primary drawbacks associated with the use of bare MNP. In addition coating with NOM can potentially increase the adsorption capacity and selectivity of the nanoparticles [36].

\section{5) Humic Acid (HA)}

Humic acid (HA), a ubiquitous natural organic matter (NOM), is derived from plants, lignite, coal, soil, leonardite and microbial residues (Figure 2). HA possesses a number of organic functional groups including carboxylic acids, carbonyl groups and phenolic hydroxyl groups which can promote its complexation with a variety of metal oxides [37] [38] [39] [40]. HA has a high affinity for magnetite $\left(\mathrm{Fe}_{3} \mathrm{O}_{4}\right)$ and effectively coats bare MNP most likely through the surface complexation ligand exchange reactions. Some studies have been reported on the removal of water contaminants using HA-MNP with primary focus on the removal of metal cations [41] [42].

Recent research activities demonstrated that the potential use of HA-MNP to successfully remove metal oxyanions (chromate), metal ions such as, $\mathrm{Cu}(\mathrm{II})$, $\mathrm{Cd}(\mathrm{II}), \mathrm{Pb}$ (II), $\mathrm{Hg}$ (II) and Rhodamine B from the aqueous media [33] [43] [44] [45] [61]. Humic acid coated magnetite nanoparticle (HA-MNP) can have tremendous application (Table 1). Among these it is used to remove heavy metals from soil and west water in different contact time and dosage of adsorbate. This seminar report has reviewed the uses of adsorption to remove phosphate from the aqueous solutions using humic acid coated magnetic iron oxide (magnetite) nanoparticles as adsorbent.

\section{Chemicals for Synthesis of Humic Acid Coated Magnetite Nanoparticles (HA-MNP)}

Di-potassium hydrogen phosphate $\left(\mathrm{K}_{2} \mathrm{HPO}_{4}>99.9 \%\right)$, ammonium hydroxide 


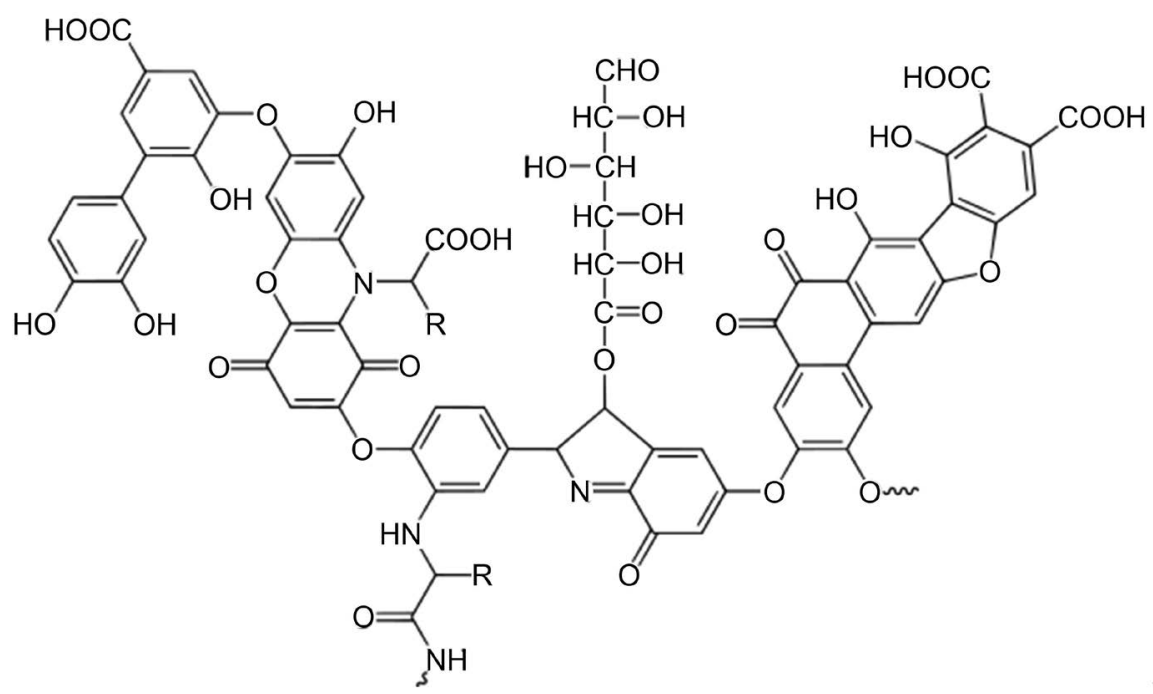

Figure 2. Model structure of humic acid [40].

$\left(\mathrm{NH}_{4} \mathrm{OH} ; 29.15 \%\right)$, sulfuric acid $\left(\mathrm{H}_{2} \mathrm{SO}_{4}>95.6 \%\right)$, ferric chloride hexahydrate $\left(\mathrm{FeCl}_{3} \cdot 6 \mathrm{H}_{2} \mathrm{O} ; 98.8 \%\right)$, sodium carbonate $\left(\mathrm{Na}_{2} \mathrm{CO}_{3} ; 100.4 \%\right)$ and sodium bicarbonate $\left(\mathrm{NaHCO}_{3} ; 99.7 \%\right), \mathrm{NaOH}$, Humic acid sodium salt and ferrous chloride tetra hydrate $\left(\mathrm{FeCl}_{2} \cdot 4 \mathrm{H}_{2} \mathrm{O}>99.0 \%\right)$ is used. In all cases, Millipore filtered water $\left(18 \mathrm{M}^{\prime} \Omega \cdot \mathrm{cm}\right)$ was used to prepare the solutions [44] [45].

\section{Synthesis of Bare $\mathrm{Fe}_{3} \mathrm{O}_{4}$ and Humic Acid Coated Magnetite Nanoparticles (HA-MNP)}

For different applications, several chemical methods can be used to synthesize magnetic nanoparticles: co-precipitation, reverse micelles and micro-emulsion technology, sol-gel syntheses, sonochemical reactions, hydrothermal reactions, hydrolysis and thermolysis of precursors, flow injection syntheses, and electrospray syntheses [46]. The synthesis of superparamagnetic nanoparticles is a complex process because of their colloidal nature. For metal removal applications, an adequate surface modification of the nanoparticles is a critical aspect regarding both selectivity and aqueous stability of these materials. To this end, in the last decade, organic and inorganic functionalized $\mathrm{Fe}_{3} \mathrm{O}_{4}$ nanoparticles have been developed and modifications of the synthesis methods mentioned above have been proposed. Among these Co-precipitation is probably the simplest and most efficient chemical pathway to obtain magnetic particles. The size and shape of the nanoparticles can be controlled by adjusting $\mathrm{pH}$, ionic strength, temperature and nature of the salts [47] [48] [49] [50].

\section{Procedure of Preparation}

The $\mathrm{Fe}_{3} \mathrm{O}_{4}$ nanoparticles and coating $\mathrm{Fe}_{3} \mathrm{O}_{4} / \mathrm{HA}$ was prepared by the co-precipitation method, $\mathrm{FeCl}_{3} \cdot 6 \mathrm{H}_{2} \mathrm{O}$ and $\mathrm{FeCl}_{2} \cdot 4 \mathrm{H}_{2} \mathrm{O}$ were dissolved into $100 \mathrm{~mL}$ of water in a three-neck round bottom flask connected with a reflux condenser. The solution was then purged with nitrogen in order to prevent $\mathrm{Fe}^{2+}$ ion oxidation. $6 \mathrm{M}$ $\mathrm{NaOH}$ was added drop-wise into the solutions, to control the size and shape of 
the nanoparticles by adjusting $\mathrm{pH}$, ionic strength, temperature and nature of the salts and purging was continued for an additional $10 \mathrm{~min}$. The mixture was then heated with magnetic stirring until the temperature reached to $90^{\circ} \mathrm{C}$. At this temperature, $10 \mathrm{~mL}$ of $25 \%$ ammonium hydroxide and $50 \mathrm{~mL}$ of $1 \%$ humic acid sodium salt were added simultaneously into the reaction mixture and kept at $90^{\circ} \mathrm{C} \pm 5^{\circ} \mathrm{C}$ for additional $30 \mathrm{~min}$. The solution was then allowed to cool, washed with water several times to separate the nanoparticles from the free iron and humic acid. Finally, the black precipitate was purified using multiple water washes with magnetic separation of particles from the supernatant. The black precipitate obtained was stored at ambient temperature as a dry black powder (in a vacuum oven at $40^{\circ} \mathrm{C}$, for $24 \mathrm{~h}$ ), ground magnetic nanoparticles were stored in a desiccator prior to use in the experiments [41] [42] [43] [44] [45] [51].

\section{Material Characterization}

Functional group of $\mathrm{Fe}_{3} \mathrm{O}_{4}, \mathrm{HA}$ and $\mathrm{HA}-\mathrm{Fe}_{3} \mathrm{O}_{4}$ can be characterized by Fourier transform infrared spectroscopy (FTIR) was performed at room temperature. The crystal structure was analyzed by X-ray diffraction (XRD). Transmission electron microscopy (TEM) is used to determine the surface morphology and microstructure of the HA-MNP. The magnetic nanoparticles properties were measured by Vibrating sample magnetometer. Spectral scans of the synthesized nanoparticles were found between $550-4000 \mathrm{~cm}^{-1}$. The samples were sonicated for $30 \mathrm{~min}$ prior to dipping onto a silicone monoxide substrate grids, dried at room temperature and then analyzed. The leaching of HA was determined by measuring total organic carbon (by TOC analyzer) in solutions at different $\mathrm{pH}$ after the separations of the synthesized [41] [42] [43] [44] [45].

\section{Characterization of the Magnetite Nanoparticles and Coated Nanoparticles}

The TEM images of HA-MNP showed high crystallinity of magnetite nanoparticles inside $\left(\mathrm{Fe}_{3} \mathrm{O}_{4}\right.$ core) and disordered structure outside which is due to the coating of humic acid on the surface of iron oxide nanoparticles [45]. Further analysis of the TEM images showed the narrow size distribution of HA-MNP in the range of $7-12 \mathrm{~nm}$ with quasi-spherical geometry. Chemical analysis of this agglomerate by energy dispersive spectroscopy (EDS) yields the elements as carbon, iron, oxygen, and silicon (silicon appeared from the TEM grids). The results confirm the composition of the HA-MNP [41] [44] [45] [51].

HR-TEM images for the HA-MNP dispersed in aqueous medium are also observed and the particles appeared to be roughly spherical in shape, with a crystalline core of $\mathrm{Fe}_{3} \mathrm{O}_{4}$ and an external layer of organic matter less than $1 \mathrm{~nm}$ in thickness, as estimated from the external halo surrounding the particles [42].

From FTIR spectra (Figure 3), the band at $1598 \mathrm{~cm}^{-1}$ in HA-MNP corresponds to the $\mathrm{C}=\mathrm{O}$ stretching of carboxylate anion of $\mathrm{HA}$ due to its interaction 


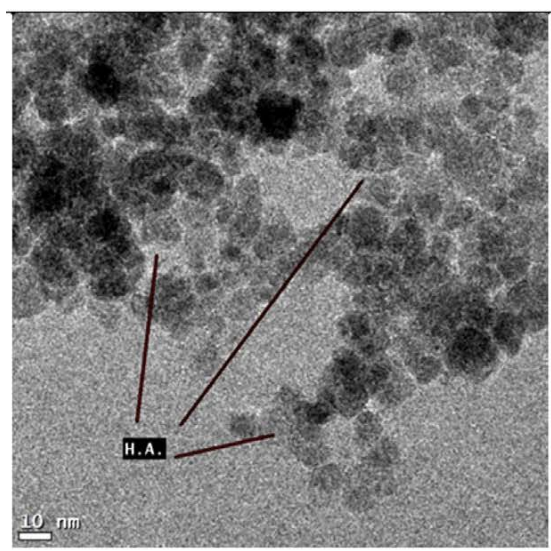

(a)

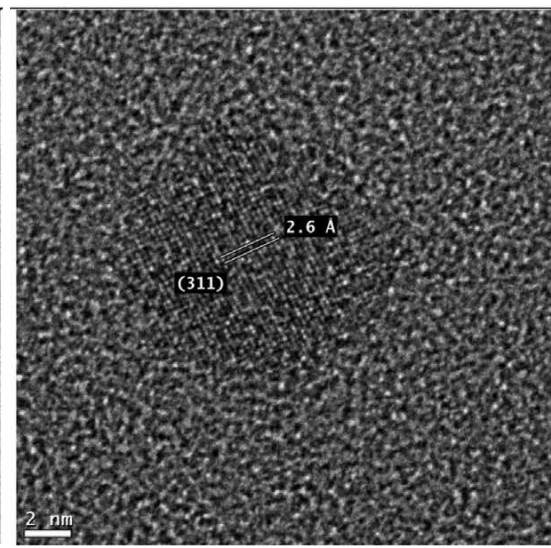

(b)

Figure 3. TEM images of HA-MNP. (a) low resolution TEM image, the red lines show the humic acid coating on MNP (b) HRTEM images shows a high crystalline structure of magnetitecore in HA-MNPs [45].

with the iron oxide surface of magnetite. The appearance of another strong band in the synthesized HA-MNP at $1398 \mathrm{~cm}^{-1}$ can be assigned to the scissoring of $-\mathrm{CH}_{2}$ group of HA [41] [42] [43] [44] [45] [52]. The band at $3331 \mathrm{~cm}^{-1}$ in HA is attributed to $\mathrm{O}-\mathrm{H}$ stretching of alcohol and/or phenol which largely disappeared in HA-MNP indicating the complexation between the magnetite core and the humic acid shell. The band at 1090 and $1009 \mathrm{~cm}^{-1}$ in HA can be ascribed to the $\mathrm{C}-\mathrm{O}$ stretching of $\mathrm{COO}^{-}$and deformation vibration of $\mathrm{C}-\mathrm{H}$ bond of benzene ring respectively. Other study shows that, the FTIR spectra of HA-MNP were confirmed that by a strong absorption at $\sim 588$ and $630 \mathrm{~cm}^{-1}$, which corresponds to $\mathrm{Fe}-\mathrm{O}$ stretching vibration. Significant differences in the bands assigned to $\mathrm{C}=\mathrm{O}$ stretches $\left(\sim 1400\right.$ and $\left.1620 \mathrm{~cm}^{-1}\right)$ are observed. These differences are consistent with the carboxylate anions interacting with the $\mathrm{FeO}$ surface and suggest that carboxylate groups indeed play an important role in the bonding of the HA to the magnetite surface. This result is in agreement with other authors and with the observed change in the $-\mathrm{COOH} / \mathrm{OH}^{-}$ratio upon binding of the HA groups to the $\mathrm{Fe}_{3} \mathrm{O}_{4}$ nanoparticles [30] [42]. From these it can be concluding that approximately similar spectra were recorded within the different study procedure.

The magnetite is an amphoteric solid, which can develop charges in the protonation and deprotonation reaction of $\mathrm{Fe}-\mathrm{OH}$ sites on surface. This process is controlled by the $\mathrm{pH}$ and ion strength in aqueous medium. At $\mathrm{pH}$ lower than the PZC (the point of zero charge) $(\mathrm{pH}<7.9)$ the surface charge is positive, electrostatic interaction between $\mathrm{HA}$ and $\mathrm{Fe}_{3} \mathrm{O}_{4}$ is dominant under acidic conditions [48] [52] [53].

$$
\mathrm{Fe}-\mathrm{OH}_{2}^{+}+\mathrm{R}-\mathrm{COO}^{-} \rightarrow \mathrm{Fe}-\mathrm{OOC}-\mathrm{R}+\mathrm{H}_{2}
$$

At above the $\mathrm{pH}$ of $\mathrm{PZC}(\mathrm{pH}>7.9)$ the surface charge is negative, the coating $\mathrm{HA}$ on $\mathrm{Fe}_{3} \mathrm{O}_{4}$ in alkaline condition, the dominant interaction between $\mathrm{HA}$ and $\mathrm{Fe}_{3} \mathrm{O}_{4}$ is probable a ligand-change reaction with surface hydroxyl occur [48] [52] [53]. 


$$
\mathrm{Fe}-\mathrm{OH}+\mathrm{R}-\mathrm{COO}^{-} \rightarrow \mathrm{Fe}-\mathrm{OOC}-\mathrm{R}+\mathrm{OH}^{-}
$$

The XRD measurement was used to identify the crystalline structure of the product. The XRD patterns of $\mathrm{Fe}_{3} \mathrm{O}_{4} / \mathrm{HA}$ and $\mathrm{Fe}_{3} \mathrm{O}_{4}$ are shown in Figure 4, two materials had similar diffraction peaks at $2 \theta=30.1^{\circ}, 35.4^{\circ}, 43.1^{\circ}, 57.0^{\circ}, 62.68^{\circ}$ and $74.5^{\circ}$. The XRD peaks can match well with the characteristic peaks of inverse cubic spinel structure. This result indicated that the crystal structure of $\mathrm{Fe}_{3} \mathrm{O}_{4}$ was not changed after modification with $\mathrm{HA}$. The average crystallite $\mathrm{d}$ calculated using the Debye-Scherrer equation $\mathrm{d}=\mathrm{n} \lambda /(\beta \cos \theta)$ are about $\mathrm{Fe}_{3} \mathrm{O}_{4}=$ $13.46 \mathrm{~nm}$ and $\mathrm{Fe}_{3} \mathrm{O}_{4} / \mathrm{HA}=10.80 \mathrm{~nm}$ [30] [41] [53] [55] [56] [57]. Other study indicate that the identity and purity of the iron oxide in $\mathrm{Fe}_{3} \mathrm{O}_{4}$ and $\mathrm{Fe}_{3} \mathrm{O}_{4} / \mathrm{HA}$ were verified by XRD. As shown in (Figure 5), XRD patterns of the $\mathrm{Fe}_{3} \mathrm{O}_{4} / \mathrm{HA}$ display several relatively strong reflection peaks in the $2 \theta$ region of $20^{\circ}-70^{\circ}$, which match well with the standard pattern of $\mathrm{Fe}_{3} \mathrm{O}_{4}$ (Figure 4). This result indicates that magnetite is the unique iron oxide species obtained from the synthesis in accordance with the HR-TEM electron diffraction results. Remnant impurities of $\mathrm{NH}_{4} \mathrm{Cl}$ crystals were also observed in the XRD pattern [42].

Generally, all results of the above studies can show similar Characterization value for the synthesized humic acid coated magnetite nanoparticles which implies that HA-MNP could be synthesized truly by considering the procedure.

\section{Adsorption Study}

\subsection{Adsorption Experiments}

Stock solution of phosphate (P) with concentration of $1000 \mathrm{mg}$ of $\mathrm{P} / \mathrm{L}(\mathrm{ppm})$ was

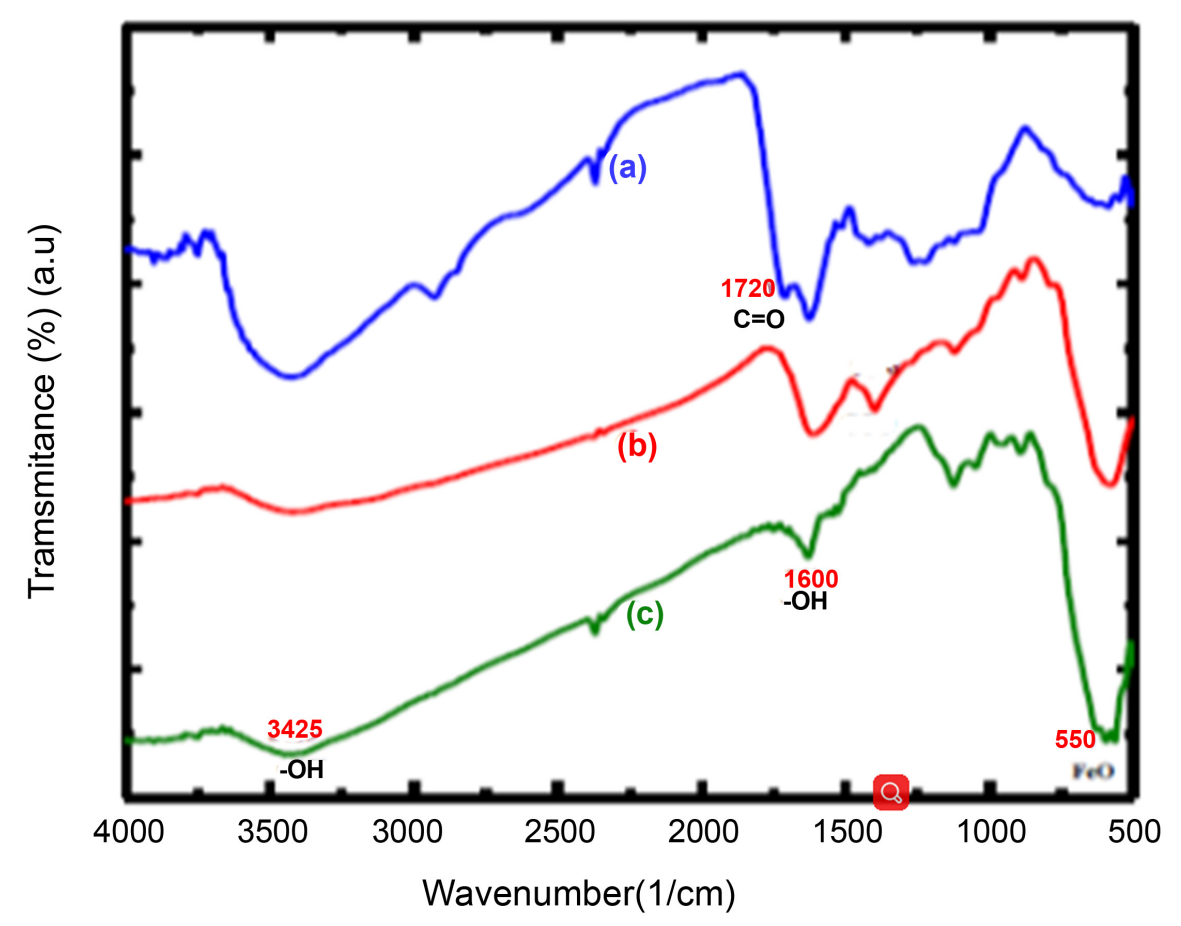

Figure 4. FTIR Spectra of humic acid (HA) (a), $\mathrm{Fe}_{3} \mathrm{O}_{4}(\mathrm{~b})$ and $\mathrm{Fe}_{3} \mathrm{O}_{4} / \mathrm{HA}$ (c) [41]. 


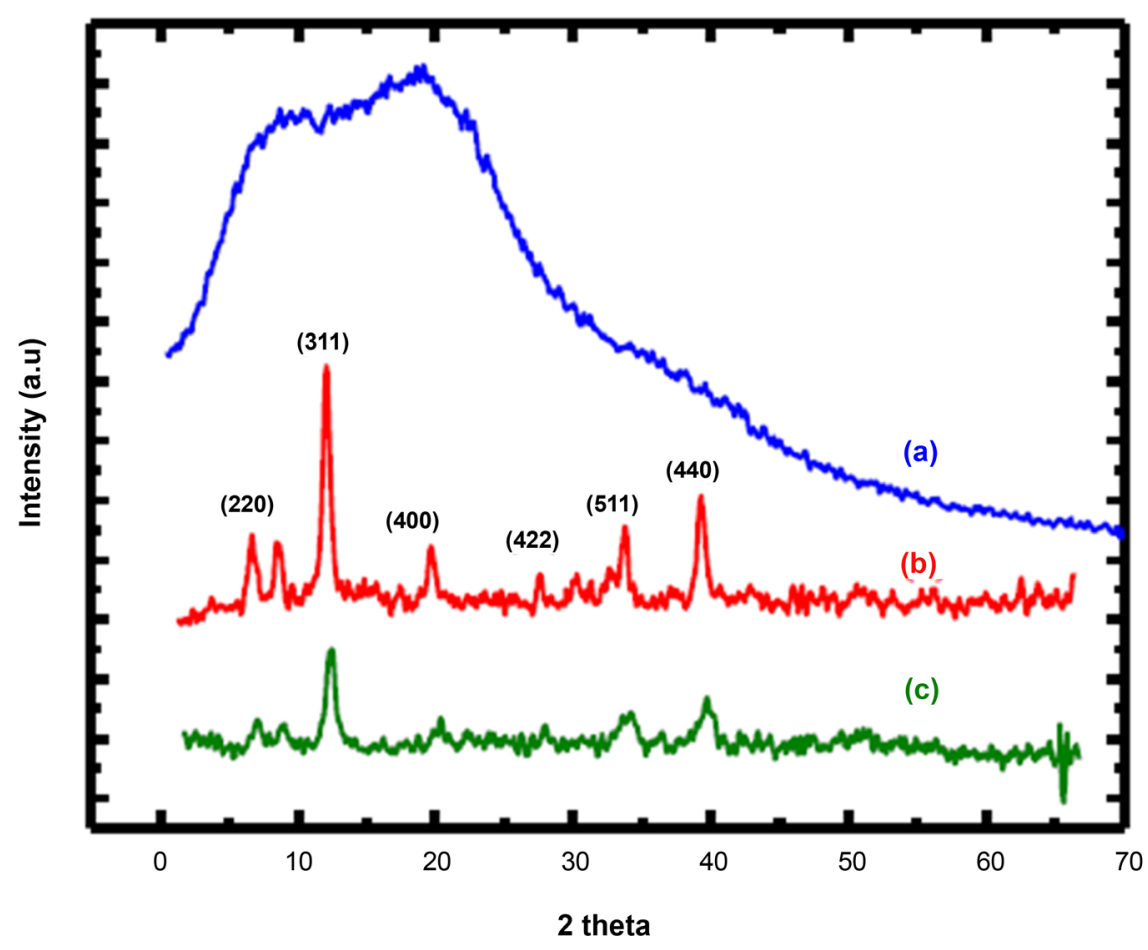

Figure 5. XRD pattern of humic acid (HA) (a), $\mathrm{Fe}_{3} \mathrm{O}_{4}$ (b) and $\mathrm{Fe}_{3} \mathrm{O}_{4} / \mathrm{HA}$ (c) [41].

prepared from di-potassium hydrogen phosphate $\left(\mathrm{K}_{2} \mathrm{HPO}_{4}\right)$ [46]. A series of standard and working solutions with concentrations ranging from 0.05 to 100 $\mathrm{mg} / \mathrm{L}$ were prepared by dilution of the stock solution. The adsorption studies were carried out in capped plastic bottles with $50 \mathrm{~mL}$ of phosphate solution as adsorbate and $0.05 \mathrm{~g}$ of HA-MNP $(1.0 \mathrm{~g} / \mathrm{L})$ as adsorbent. To ensure efficient mixing and proper mass transfer, the samples were placed in the orbit shaker and shaken at $250 \mathrm{rpm}$ for a specific time period. All the experiments were conducted at room temperature $(298 \mathrm{~K})$ with a $\mathrm{pH} 6.6 \pm 0.1$ except the studies investigating the temperature and $\mathrm{pH}$ effects. For the $\mathrm{pH}$ experiments, 0.1 $\mathrm{MNaOH}$ and $0.1 \mathrm{MHCl}$ were used to adjust the initial solution $\mathrm{pH}$, confirmed in the $\mathrm{pH}$ meter. In case of thermodynamic study, sample solutions were placed in the thermostat water bath to maintain the desired temperature. In all instances, the sample solutions were separated from the adsorbent nanoparticles using a simple handheld magnet [43] [44] [45]. The equilibrium of phosphate adsorpion was calculated by using the following equation:

$$
Q_{e}=\frac{\left(C_{o}-C_{e}\right)}{m} V
$$

where $Q_{e}$ is the amount of phosphate adsorbed $(\mathrm{mg} / \mathrm{g})$ at equilibrium, $C_{o}$ and $C_{e}$ corresponds to the initial and equilibrium concentration of phosphate in solution respectively, expressed in $\mathrm{mg} / \mathrm{L} ; \mathrm{m}$ is the mass $(\mathrm{g})$ of the adsorbent (HA-MNP) and $V$ is the total volume (L) of the solution. Reproducibility of the collected data was ensured by taking the average of triplicate run of the experiments [45]. 
The phosphate removal efficiency or phosphate removal percentage $(\eta)$ was calculated through the following equation:

$$
\eta=\frac{C_{o-} C_{e}}{C_{0}} \times 100 \%
$$

\subsection{Adsorption Kinetics}

The adsorption of phosphate on HA-MNP surface increased with time and dosage. As different studies indicated adsorption equilibrium reached within a given minute with $>90 \%$ of phosphate removed from the solution in $3 \mathrm{~h}$ for an initial phosphate concentration of 2 ppm [46]. Table 2 shows maximum adsorption ability of different adsorbent.

Among different adsorbent humic acid coated magnetite nanoparticles economical, simple and ease of separation of adsorbent and adsorbate. Surface saturation occurs at higher initial phosphate concentration and the adsorption rate became slower. The kinetic data could be fit to both pseudo-first order and pseudo-second order kinetic models (Equation (5) and Equation (6) respectively) and compared, to provide insights of adsorption mechanisms such as mass transfer and chemical reaction. It is well established that the pseudo-first order kinetic model fits better in the initial stage of reaction processes especially those with rapid adsorption, whereas the pseudo-second order model considers adsorption behavior over longer contact times with chemisorption as the rate controlling process [8] [35] [45] [51] [76].

$$
\begin{gathered}
\log \left(Q_{e}-Q_{t}\right)=\log Q_{e}-\frac{k_{1} t}{2.303} \\
\frac{t}{Q_{t}}=\frac{1}{k_{2} Q_{e}^{2}}+\frac{1}{Q_{e}} t
\end{gathered}
$$

\begin{tabular}{|c|c|c|c|c|c|}
\hline No. & Adsorbent types & Adsorption of Phosphate & Temp. \& pH & Isotherms & Ref. \\
\hline 1 & Humic acid coated magnetite nanoparticles & $28.9 \mathrm{mg} / \mathrm{g}$ & $298 \mathrm{~K} \& 6.6$ & Freundlich model & [45] \\
\hline 2 & $\begin{array}{l}\text { Organism combined with magnetic sorbent } \\
\left.\mathrm{Fe}_{3} \mathrm{O}_{4} \text { core-shell(MFC@ } \mathrm{La}(\mathrm{OH})_{3}\right)\end{array}$ & $45.45 \mathrm{mg} / \mathrm{g}$ & $30^{\circ} \mathrm{C} . \& 6.5-7$ & Langmuir model & [7] \\
\hline 3 & Amine-functionalized copper ferrite chelated with $\mathrm{La}$ (III) & $32.59 \mathrm{mg} / \mathrm{g}$ & $298 \mathrm{~K} \& 5.5$ & Freundlich model & [9] \\
\hline 4 & $\begin{array}{l}\mathrm{Fe}_{3} \mathrm{O}_{4} @ \mathrm{SiO}_{2} \text { core/shell magnetic nanoparticles } \\
\text { functionalized with lanthanum oxide }\end{array}$ & $27.8 \mathrm{mg} / \mathrm{g}$ & Not reported & Lang muir model & [34] \\
\hline 5 & Magnetite nanoparticles & $3.65 \mathrm{mg} / \mathrm{g}$ & $318 \mathrm{~K} \& 2.77$ & Langmuir model & [35] \\
\hline 6 & $\begin{array}{l}\text { Novel magnetic nanocomposites with } \mathrm{Fe}_{3} \mathrm{O}_{4} @ \mathrm{SiO}_{2} \text { core and } \\
\text { mesoporous } \mathrm{CeO}_{2} \text { shell }\end{array}$ & $64.07 \mathrm{mg} / \mathrm{g}$. & Not reported & Langmuir model & [63] \\
\hline 7 & Synthesized magnetite & $15.2 \mathrm{mg} \mathrm{P} / \mathrm{g}$ & $298 \&<5$ & Freundlich model & [51] \\
\hline 8 & Synthesis of magnetite core/zirconia shell nanocomposite & $42.19 \mathrm{mg} / \mathrm{g}$, & $298 \&<5.5$ & Langmuir model & {$[8]$} \\
\hline 9 & La-EDTA coated $\mathrm{Fe}_{3} \mathrm{O}_{4}$ & 4.2 & $298 \& 6.0$ & Freundlich model & [26] \\
\hline 10 & Hematite & 1.1 & $298 \& 6.0$ & Freundlich model & [35] \\
\hline 11 & $\alpha-\mathrm{Fe}_{2} \mathrm{O}_{3}$ & 0.6 & $298 \& 3.0$ & Freundlich model & [35] \\
\hline
\end{tabular}

Table 2. Maximum Adsorption ability of different adsorbent. 
where $Q_{t}$ and $Q_{e}$ are the amount of phosphate adsorbed on the adsorbent surface $(\mathrm{mg} / \mathrm{g})$ at time $\mathrm{t}$ and at equilibrium respectively. $K_{1}$ and $K_{2}$ are the rate constants of the pseudo-first order and pseudo-second order rate equation respectively. In both cases, $t$, is the time in minutes.

The results of different studies illustrate that the adsorption of phosphate on HA-MNP likely occurs through chemisorption where sharing or exchange of electron takes place between phosphate and the functional groups of humic acids of HA-MNP [30] [59] [60] [61] [62]. In the typical pseudo-second order process, an initial surface reaction occurs until all the surface sites are occupied; subsequently diffusion and molecular reorganization can take place at the surface for additional complexation. In addition the pseudo-first order kinetic model also exhibits a good correlation after fitting the experimental data, however, significant deviation was observed between the two $Q_{e}$ values indicating that this model is not consistent with the observed phosphate adsorption [45] [56]. To further explore the adsorption process, the kinetic data were also examined using the Weber and Morris intraparticle diffusion model that expresses the fraction of solute adsorbed as a function of square root of time [45].

$$
Q_{t}=k_{i d} \sqrt{t}+C
$$

where $Q_{t}$ is the amount of phosphate adsorbed at time $t$ (minute), $k_{i d}$ is the intraparticle diffusion rate constant and C is the intercept. A plot of $Q_{t}$ vs $\sqrt{t}$ yielded a linear relationship which did not pass through the origin. The results suggest that intraparticle diffusion is involved in the overall adsorption process although it is not the rate limiting step. Additionally, the observed multilinearity can be attributed to the involvement of two or more steps in the adsorption process [1] [34] [43] [56]. The external adsorption process is assumed to be the fastest and instantaneous where a significant concentration of initial phosphate was adsorbed in the HA-MNP surface within $10 \mathrm{~min}$. The second stage of adsorption was controlled by intraparticle diffusion mechanism over a period of approximately $60 \mathrm{~min}$. The final stage is the equilibrium adsorption where intraparticle diffusion no longer dominates due to low phosphate concentration and the process approaches the equilibrium [7] [8] [35] [45] [51].

\section{Adsorption Isotherms}

The adsorption isotherm describes the adsorbent-adsorbate relationship at equilibrium critical for determining optimal parameters for the application of the adsorbent. A range of concentrations of phosphate were mixed with a fixed amount of HA-MNP $(1 \mathrm{~g} / \mathrm{L})$. The experiment was carried out for $3 \mathrm{~h}$ in the orbit shaker at temperature $298 \mathrm{~K}, \mathrm{pH} 6.6$ and a mixing speed of $250 \mathrm{rpm}$. The concentrations of phosphate obtained were plotted as adsorption isotherms and fit to Langmuir and Freundlich models to determine the equilibrium adsorption and the maximum adsorption capacity. The Langmuir isotherm assumes that monolayer adsorption occurs on homogeneous adsorbent surface and there is no interaction between the adsorbate molecules [76]. In the case of magnetite the 
singly coordinated surface hydroxyl groups, here, phosphate oxygen (P-O) is replacing hydroxyl oxygen $(\mathrm{OH})$ on the magnetite surface (i.e., ligand exchange) [1] [34] [57]. The linear form of Langmuir adsorption isotherm is represented below, Equation (8),

$$
\frac{C_{e}}{Q_{e}}=\frac{1}{b Q_{\max }}+\frac{C_{e}}{Q_{\max }}
$$

where, $C_{e}$ is the concentration of phosphate $(\mathrm{mg} / \mathrm{L})$ in solution at equilibrium, $Q_{e}$ is the amount of phosphate adsorbed $(\mathrm{mg} / \mathrm{g})$ on the adsorbent surface at equilibrium, $Q_{\max }$ is the maximum adsorption capacity $(\mathrm{mg} / \mathrm{g})$ and $b$ is the Langmuir constant related to adsorption free energy (L/mg). The Freundlich isotherm, on the other hand, describes the heterogeneity of the adsorbent surface with non-uniform distribution of adsorption heat and affinities as well as the formation of multilayer during the adsorption process [30] [34] [76]. The mathematical expression of Freundlich isotherm is represented below, Equation (9),

$$
\log \left(Q_{e}\right)=\log K_{f}-\frac{1}{n} \log C_{e}
$$

where $Q_{e}$ and $C_{e}$ represent the same parameter as in Langmuir isotherm, $\mathrm{K}_{\mathrm{f}}$ denotes the adsorption capacity and $1 / \mathrm{n}$ indicates adsorption intensity (dimensionless). The value of $K_{f}$ is linearly proportional to adsorption capacity while a $1 / \mathrm{n}$ value of less than 1 indicates greater adsorption strength through chemisorption. Plotting graph of $\log \left(Q_{e}\right) \mathrm{Vs} \log C_{e}$, slope $=1 / \mathrm{n}$ and an intercept is= $\log K_{f}$

The theoretical maximum adsorption capacity for phosphate was calculated to be $28.9 \mathrm{mg} / \mathrm{g}(\mathrm{P})$ which is comparable to other similar types of adsorbents used for phosphate removal which listed Table 1 at a given temperature and $\mathrm{pH}$. The authors also showed that the Freundlich isotherm model explains $\left(\mathrm{R}^{2}>0.93\right)$ the adsorption process better than the Langmuir isotherm $\left(\mathrm{R}^{2}=0.80\right)$ and thus indicative of the formation of multilayer adsorption and heterogeneous surface sites. The value of $1 / \mathrm{n}$ was found to be less than unity (0.48) which corresponds to an adsorption mechanism involving chemisorption, supported by kinetic study [45].

\subsection{Effect of $\mathrm{pH}$}

Solution $\mathrm{pH}$ can have a pronounced effect on adsorption since the adsorbent surface charge strongly influence the adsorption of charged phosphate species. The leaching of humic acid from the HA-MNP surface is also affected by solution $\mathrm{pH}$. With this in mind, the adsorption of phosphate was studied as a function of initial solution $\mathrm{pH}$ from acidic to alkaline range [34] [45] [59]. The amount of phosphate removal decreased with the increase of $\mathrm{pH}$ values, Figure 6. The lower adsorption at basic $\mathrm{pH}$ can be explained by considering the phosphate speciation in aqueous medium. Phosphate is polyacidic $\left(\mathrm{pK}_{1}=2.12, \mathrm{pK}_{2}=\right.$ 7.21, and $\mathrm{pK}_{3}=12.67$ ) prevail as $\mathrm{H}_{3} \mathrm{PO}_{4}, \mathrm{H}_{2} \mathrm{PO}_{4}^{-}, \mathrm{HPO}_{4}^{2-}$ and $\mathrm{PO}_{4}^{3-}$ in water. At 


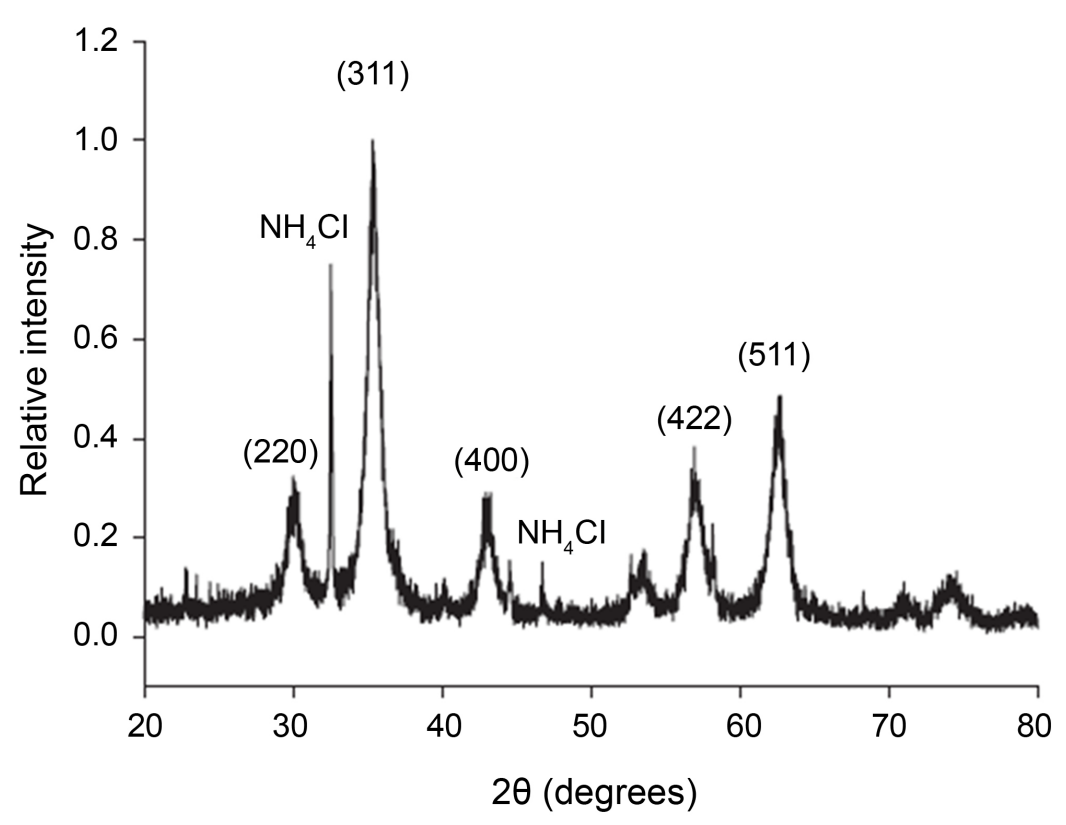

Figure 6. XRD pattern obtained for $\mathrm{Fe}_{3} \mathrm{O}_{4} / \mathrm{HA}$ [43].

lower $\mathrm{pH}$, sorbent surface will be positively charged while the phosphate species will be predominantly monoanionic which is $\mathrm{H}_{2} \mathrm{PO}_{4}^{-}$[45] [60]. Thus electrostatic attraction between $\mathrm{H}_{2} \mathrm{PO}_{4}^{-}$and $\mathrm{HA}-\mathrm{MNP}-\mathrm{H}^{+}$results in higher adsorption of $\mathrm{PO}_{4}^{3-}$ on HA-MNP. As the $\mathrm{pH}$ increases, more hydroxyl ion exists in the solution which might compete with phosphate species for the sorbent site. Another possibility is that, at higher $\mathrm{pH}$, the sorbent surface and the $\mathrm{PO}_{4}^{3-}$ species becomes more negative which introduces greater repulsion and as a consequence, the adsorption of $\mathrm{PO}_{4}^{3-}$ decreases [1] [34] [45] [52].

This implies that by using a strongly basic solution, it was expected that most of the adsorbed phosphate would be desorbed because of the effect of $\mathrm{pH}$ on adsorption [1] [34]. The amount of phosphate desorbed was calculated by the following equation:

$$
Q_{d}=C_{d} \times \frac{V}{m}
$$

The desorption efficiency was calculated by the following equation:

$$
\eta=\frac{Q_{d}}{Q_{e}} \times 100 \%
$$

where $C_{d}$ is the concentration of phosphate in supernatant after desorption $(\mathrm{mgP} / \mathrm{L}) ; V$ is the volume of $\mathrm{NaOH}$ solution added as desorption reagent $(\mathrm{L}) ; Q_{c}$ is the amount of phosphate adsorbed (mg/g) (Figure 7).

\subsection{Effect of Temperature}

Thermodynamic study of phosphate adsorption was conducted by measuring the adsorption at different temperatures) with an initial concentration of phosphate and $1 \mathrm{~g} / \mathrm{L}$ of HA-MNP. The reaction time was $1 \mathrm{~h}$. By fitting each of these 




Figure 7. Effect of initial $\mathrm{pH}$ for the adsorption of phosphate onto HA-MNP. Initial phosphate concentration $=5 \mathrm{mg} / \mathrm{L}, \mathrm{HA}-\mathrm{MNP}$ dose $=1.0 \mathrm{~g} / \mathrm{L}$, temperature $=298 \mathrm{~K}$, contact time $=1 \mathrm{~h}$.

temperature data into the pseudo second order model different rate constants were obtained for different temperatures. A plot of $\ln k$ vs $1 / T$ was used to determine the activation energy $\left(E_{a}\right)$ based on Arrhenius equation:

$$
\ln k=\ln K_{o}-\frac{E_{a}}{R T}
$$

where $E_{a}$ is the activation energy $(\mathrm{KJ} / \mathrm{mol}), K_{o}$ is the temperature independent factor, $R$ is the ideal gas constant $(8.314 \mathrm{~J} / \mathrm{K} \mathrm{mol})$ and $T$ is the temperature in Kelvin. The plot gives a straight line from where the value of $E_{a}$ is calculated, which also suggests that the adsorption process is mostly driven by the mechanism of chemisorption [34] [45] [59] [60].

Other important thermodynamic parameters were calculated by using the following equations

$$
\begin{gathered}
\log \frac{Q_{e}}{C_{e}}=\frac{\Delta S^{\mathrm{o}}}{2.303 R}-\frac{\Delta H^{\mathrm{o}}}{2.303 R T} \\
\Delta G^{\mathrm{o}}=\Delta H^{\mathrm{o}}-T \Delta S^{\mathrm{o}}=-R T \operatorname{lan} K_{C}
\end{gathered}
$$

where $R$ is the gas constant, $K_{C}$ is the equilibrium constant and $T$ is the temperature in $K$. The $K_{C}$ value is calculated from Equation (10):

$$
K_{C}=\frac{Q_{e}}{C_{e}}
$$

Standard enthalpy $\left(\Delta H^{\circ}\right)$ and entropy $\left(\Delta S^{\circ}\right)$, of adsorption can be estimated from van't Hoff equation given in Equation (9) and Equation (11)

$$
\operatorname{lan} K_{C}=\frac{-\Delta H^{\circ}}{R T}+\frac{\Delta S^{\circ}}{R}
$$

where $\Delta G^{\circ}, \Delta H^{\circ}$ and $\Delta S^{\circ}$ are the standard free energy, enthalpy and entropy for the adsorption process respectively, $Q_{e}$ is the amount of phosphate adsorbed at equilibrium $(\mathrm{mg} / \mathrm{g}), C_{e}$ is the equilibrium concentration $(\mathrm{mg} / \mathrm{L})$ of phosphate in solution and $T$ is the temperature (K). Results of different studies show that the positive value of $\Delta H^{p}$, which indicate, the process is endothermic i.e. adsorption 
increases with the increase of temperature which might result from the fact that rising temperature increases the adsorbent pore size and/or favor the mass transport by reducing the reaction energy barrier between the phosphate ions and the HA-MNP. The positive value of $\Delta S^{\circ}$ implies that randomness of the system increases at the solid solution interface which helps the adsorption of phosphate onto the surface of HA-MNP. The negative value of $\Delta G^{\circ}$ indicates that the overall adsorption process is spontaneous and therefore, thermodynamically favorable at all the investigated temperatures [41] [44] [45] (Figure 8 \& Figure 9).

\subsection{Effect of Coexisting Ions}

In groundwater and wastewater, anions such as sulfate, nitrate chloride and carbonate often coexist along with $\mathrm{PO}_{4}^{3-}$, so the effect of coexisting ions was also studied by separately adding $1 \mathrm{mM}$ of each of the anions into the reaction mixtures containing affixed amount of $\mathrm{PO}_{4}^{3-}$ and HA-MNP. Different authors indicated that after the reaction was continued for more than an hour, except

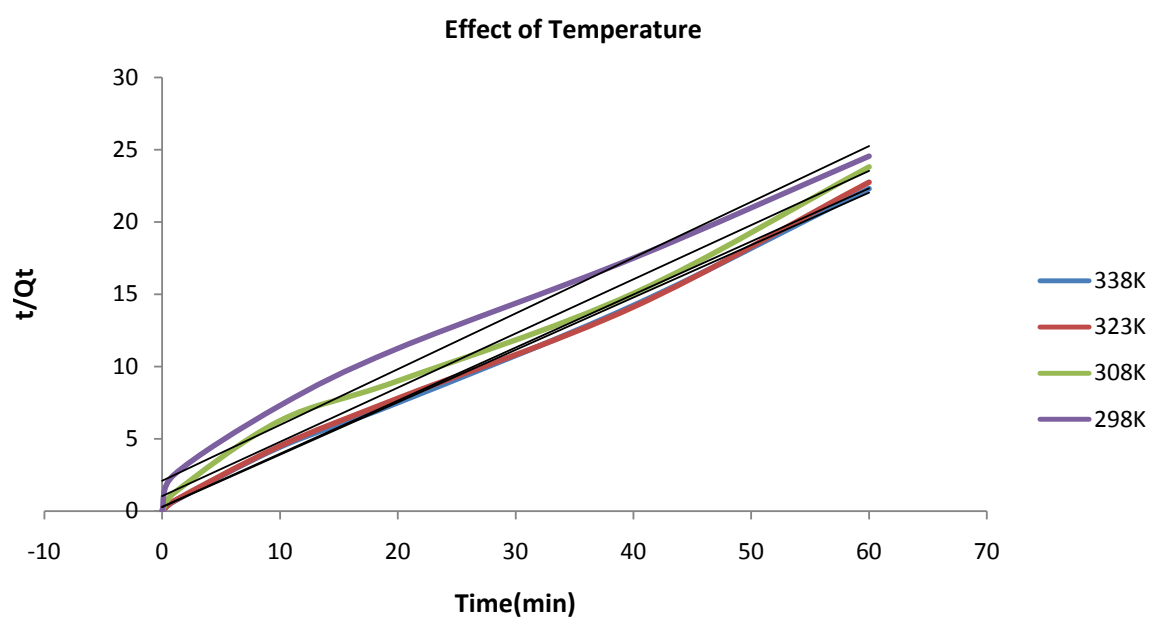

Figure 8. Effect of temperature for the adsorption of phosphate onto HA-MNP. Initial phosphate concentration $=5 \mathrm{mg} / \mathrm{L}, \mathrm{pH}=6.6, \mathrm{HA}-\mathrm{MNP}$ dose $=1.0 \mathrm{~g} / \mathrm{L}$, contact time $=1 \mathrm{~h}$.

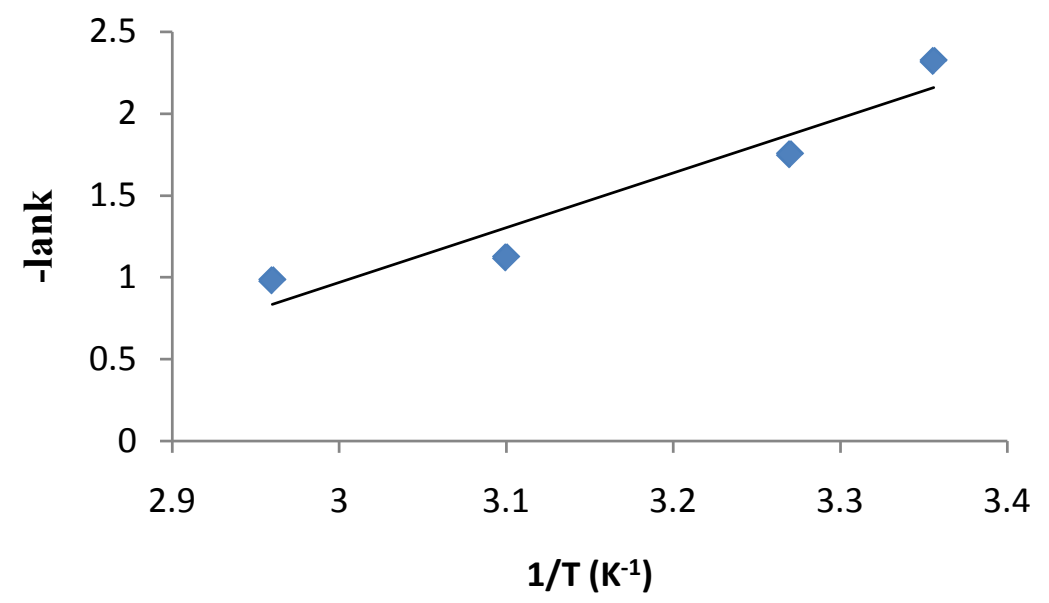

Figure 9. Arrhenius plot of lnk vs $1 / \mathrm{T}$ to determine activation energy. 
carbonate, no noticeable effect in the adsorption efficiency was observed due to the presence of any other anions in the solution. The addition of carbonate $\left(\mathrm{CO}_{3}^{2-}\right)$ made the overall phosphate solution alkaline by changing the $\mathrm{pH}$ from the initial 6.6 to 10.1. This higher $\mathrm{pH}$ might be the reason for the decrease of phosphate uptake by HA-MNP as observed the similar trend in $\mathrm{pH}$ effect study section [1] [9] [34] [41] [45] [60]. Furthermore, increasing both $\mathrm{NaOH}$ concentration and temperature resulted in an enhancement of desorption efficiency. Thus $\mathrm{NaOH}$ solution could be used to desorb phosphate adsorbed on the material for reuse, by adopting a high $\mathrm{NaOH}$ concentration and/or a high temperature [9] [60].

\section{Conclusion}

Effective removal of phosphate from water is critical to counteract eutrophication and restore water quality. Eutrophication has become a worldwide environmental problem and removing phosphate from water/wastewater by adsorption before discharge is essential. This review, focused on an environmentally friendly magnetic adsorbent has been applied to effectively separate phosphate present in the aqueous media and focused on humic acid coated magnetite nanoparticle (HA-MNP). The materials were characterized with X-ray diffraction, transmission electron microscope; vibrating sample magnetometer and Fourier transform infrared spectra. The FT-IR spectra reveal that HA has been successfully coated onto surface of $\mathrm{Fe}_{3} \mathrm{O}_{4}$ by chemical bond. The modification $\mathrm{HA}$ on $\mathrm{Fe}_{3} \mathrm{O}_{4}$ does not affect the crystals structure, decrease the saturation magnetization and excellent dispersion, which indicated HA efficiently, reduces their aggregation. Data of adsorption kinetics were fitted well to the pseudo-second-order model and effects of solution $\mathrm{pH}$, coexisting anions $\left(\mathrm{Cl}^{-}\right.$, $\mathrm{NO}_{3}^{-}, \mathrm{SO}_{4}^{2-}$ ) and temperature on phosphate adsorption were also investigated, which showed that the adsorbent had good selectivity for phosphate. The increase of temperature also exerts a positive influence on phosphate adsorption efficiency and investigations of adsorption kinetics and adsorption isotherm suggest that the adsorption mainly occurs through chemisorption and thus indicative of strong bonding between phosphate and the adsorbent nanoparticles. Thermodynamic study identified the removal process as endothermic and spontaneous.

\section{Acknowledgements}

I would like to express my sincere thanks to Wachemo University for Sponsorship, Dr. Tajeldin Alansi and Dr. Eshetu Bekele for their invaluable suggestion, guidance and friendly approach throughout this work.

I would like to acknowledge Adama Science and Technology University for giving chance to pursue $\mathrm{PhD}$ program and lastly but not the least my acknowledgement is also extended to my lovely spouse Birhan Ewnetu for her support morally, financially and for her patience. 


\section{Conflicts of Interest}

The authors declare no conflicts of interest regarding the publication of this paper.

\section{References}

[1] Adva, Z.M., Raphael, S. and Hilla, S. (2011) Adsorption-Desorption Mechanism of Phosphate by Immobilized Nano-Sized Magnetite Layer: Interface and Bulk Interactions. Journal of Colloid and Interface Science, 363, 608-614. https://doi.org/10.1016/j.jcis.2011.07.062

[2] Australian and New Zealand Environment and Conservation Council and Agriculture and Resource Management Council of Australia and New Zealand, 2000.

[3] Ye, Y.Y., Ngo, H.N., Guo, W.S., Liu, Y.W., Li, J.X., Liu, L., Zhang, X.B. and Jia, H. (2017) Insight into Chemical Phosphate Recovery from Municipal Wastewater. Science of the Total Environment, 576, 159-171. https://doi.org/10.1016/j.scitotenv.2016.10.078

[4] USEPA (2000) Nutrient Criteria Technical Guidance Manual, Office of Science and Technology, U.S. EPA, Washington, DC.

[5] Li, N., Tian, Y., Zhao, J.H., Zhan, W., Du, J.Y., Kong, L.C. and Zhang, J. (2018) Ultrafast Selective Capture of Phosphorus from Sewage by 3D Fe $\mathrm{O}_{4} @ \mathrm{ZnO}$ via Weak Magnetic Field Enhanced Adsorption. Chemical Engineering Journal, 341, 289-297. https://doi.org/10.1016/j.cej.2018.02.029

[6] Lukas, E., Helmut, R. and Matthias, Z. (2015) Overview and Description of Technologies for Recovering Phosphorus from Municipal Wastewater. Resources, Conservation and Recycling, 105, 325-346. https://doi.org/10.1016/j.resconrec.2015.09.016

[7] Liu, T., Chen, X., Wang, X., Zheng, S.R. and Yang, L.Y. (2018) Highly Effective Wastewater Phosphorus Removal by Phosphorus Accumulating Organism Combined with Magnetic Sorbent Magnetic $\mathrm{Fe}_{3} \mathrm{O}_{4}$ Core-Shell(MFC)@La(OH) . Chemical Engineering Journal, 335, 443-449. https://doi.org/10.1016/j.cej.2017.10.117

[8] Wang, Z., Xing, M.C., Fang, W.K. and Wu, D.Y. (2016) One-Step Synthesis of Magnetite Core/Zirconia Shell Nanocomposite for High Efficiency Removal of Phosphate from Water. Applied Surface Science, 366, 67-77.

https://doi.org/10.1016/j.apsusc.2016.01.059

[9] Gu, W., Li, X.D., Xing, M.C., Fang, W.K. and Wu, D.Y. (2018) Removal of Phosphate from Water by Amine-Functionalized Copper Ferrite Chelated with La(III). Science of the Total Environment, 619-620, 42-48. https://doi.org/10.1016/j.scitotenv.2017.11.098

[10] Chris, P., Simon, P., Ana, S. and Ben, M. (2012) Biologically and Chemically Mediated Adsorption and Precipitation of Phosphorus from Wastewater. Current Opinion in Biotechnology, 23, 890-896. https://doi.org/10.1016/j.copbio.2012.07.003

[11] Oehmen, A., Lemos, P.C., Carvalho, G., Yuan, Z., Keller, J., Blackall, L.L. and Reis, M.A. (2007) Advances in Enhanced Biological Phosphorus Removal: From Micro to Macro Scale. Water Research, 41, 2271-2300. https://doi.org/10.1016/j.watres.2007.02.030

[12] De-Bashan, L.E. and Bashan, Y. (2004) Recent Advances in Removing Phosphorus from Waste Water and Its Future Use as Fertilizer. Water Research, 38, 4222-4246. https://doi.org/10.1016/j.watres.2004.07.014

[13] Kumar, M., Badruzzaman, M., Adham, S. and Oppenheimer, J. (2007) Beneficial Phosphate Recovery from Reverse Osmosis (RO) Concentrates of an Integrated 
Membrane System Using Polymeric Ligand Exchanger (PLE). Water Research, 41, 2211-2219. https://doi.org/10.1016/j.watres.2007.01.042

[14] Rodrigues, L.A. and da Silva, M.L. (2009) An Investigation of Phosphate Adsorption from Aqueous Solution onto Hydrous Niobium Oxide Prepared by Co-Precipitation Method. Colloids and Surfaces A, 334, 191-196. https://doi.org/10.1016/j.colsurfa.2008.10.023

[15] Peleka, E.N. and Deliyanni, E.A. (2009) Adsorptive Removal of Phosphates from Aqueous Solutions. Desalination, 245, 357-371. https://doi.org/10.1016/j.desal.2008.04.050

[16] Mahmud, H.N., Huq, A.K. and Yahya, R.B. (2016) The Removal of Heavy Metal Ions from Wastewater/Aqueous Solution Using Polypyrrole-Based Adsorbents. RSC Advances, 6, 14778-14791. https://doi.org/10.1039/C5RA24358K

[17] Vunain, E., Mishra, A.K. and Mamba, B.B. (2016) Dendrimers, Mesoporous Silica and Chitosan-Based Nanosorbents for the Removal of Heavy-Metal Ions. A Review. International Journal of Biological Macromolecules, 86, 570-586. https://doi.org/10.1016/j.ijbiomac.2016.02.005

[18] Yu, J.G., Yue, B.Y., Wu, X.W., Liu, Q., Jiao, F.P., Jiang, X.Y. and Chen, X.Q. (2016) Removal of Mercury by Adsorption: A Review. Environmental Science and Pollution Research International, 23, 5056-5076. https://doi.org/10.1007/s11356-015-5880-x

[19] Weiya, H., Yuanming, Z. and Dan, L. (2017) A Review on Adsorptive Removal of Rhosphate from Water Using Mesoporous Materials. Journal of Environmental Management, 193, 470-482. https://doi.org/10.1016/j.jenvman.2017.02.030

[20] Xiong, W., Tong, J., Yang, Z., Zeng, G., Zhou, Y., Wang, D., Song, P., Xu, R., Zhang, C. and Cheng, M. (2017) Adsorption of Phosphate from Aqueous Solution Using Iron-Zirconium Modified Activated Carbon Nanofiber: Performance and Mechanism. Journal of Colloid and Interface Science, 493, 17-23. https://doi.org/10.1016/j.jcis.2017.01.024

[21] Yoon, S.-Y., et al. (2014) Kinetic, Equilibrium and Thermodynamic Studies for Phosphate Adsorption to Magnetic Iron Oxide Nanoparticles. Journal of Chemical Engineering, 236, 341-347. https://doi.org/10.1016/j.cej.2013.09.053

[22] Gu, W., Xie, Q., Xing, M. and Wu, D. (2017) Enhanced Adsorption of Phosphate onto Zinc Ferrite by Incorporating Cerium. Chemical Engineering Research and Design, 117, 706-714. https://doi.org/10.1016/j.cherd.2016.11.026

[23] Tu, Y.-J. and You, C.-F. (2014) Phosphorus Adsorption onto Green Synthesized Nano-Bimetal Ferrites: Equilibrium, Kinetic and Thermodynamic Investigation. Chemical Engineering Journal, 251, 285-292.

https://doi.org/10.1016/j.cej.2014.04.036

[24] Wang, W., Zhou, J., Wei, D., Wan, H., Zheng, S., Xu, Z. and Zhu, D. (2013) $\mathrm{ZrO}_{2}$-Functionalized Magnetic Mesoporous $\mathrm{SiO}_{2}$ as Effective Phosphate Adsorbent. Journal of Colloid and Interface Science, 407, 442-449. https://doi.org/10.1016/j.jcis.2013.06.053

[25] Xin, X., Wei, Q., Yang, J., Yan, L., Feng, R., Chen, G., Du, B. and Li, H. (2012) Highly Efficient Removal of Heavy Metal Ions by Amine-Functionalized Mesoporous $\mathrm{Fe}_{3} \mathrm{O}_{4}$ Nanoparticles. Chemical Engineering Journal, 184, 132-140. https://doi.org/10.1016/j.cej.2012.01.016

[26] Zou, Z.Y., Shi, Z. and Deng, L. (2017) Highly Efficient Removal of $\mathrm{Cu}(\mathrm{II})$ from Aqueous Solution Using A Novel Magnetic EDTA Functionalized $\mathrm{CoFe}_{2} \mathrm{O}_{4}$. RSC Advances, 7, 5195-5205. https://doi.org/10.1039/C6RA26821H 
[27] Xie, J., Lin, Y., Li, C., Wu, D. and Kong, H. (2015) Removal and Recovery of Phosphate from Water by Activated Aluminum Oxide and Lanthanum Oxide. Powder Technology, 269, 351-357. https://doi.org/10.1016/j.powtec.2014.09.024

[28] Diego, C., Karin, F., Laura, M., Fabrizio, S. and Gianni, T. (2016) Eutrophication Management in Surface Waters Using Lanthanum Modified Bentonite: A Review. Water Research, 97, 162-174. https://doi.org/10.1016/j.watres.2015.11.056

[29] Jianyong, L., Lihua, W., Ling, Z. and Qi, Z. (2011) Effect of pH, Ionic Strength, and Temperature on the Phosphate Adsorption onto Lanthanum-Doped Activated Carbon Fiber. Journal of Colloid and Interface Science, 364, 490-496.

[30] Maity, D. and Agrawal, D.C. (2007) Synthesis of Iron Oxide Nanoparticles under Oxidizing Environment and Their Stabilization in Aqueous and Non-Aqueous Media. Journal of Magnetism and Magnetic Materials, 308, 46-55. https://doi.org/10.1016/j.jmmm.2006.05.001

[31] Almeelbi, T. and Bezbaruah, A. (2012) Aqueous Phosphate Removal Using Nanoscale Zero-Valent Iron. Journal of Nanoparticle Research, 14, Article ID: 900. https://doi.org/10.1007/978-3-319-05041-6_16

[32] Zhang, G., Liu, H., Liu, R. and Qu, J. (2009) Removal of Phosphate from Water by Fe-Mn Binary Oxide Adsorbent. Journal of Colloid and Interface Science, 335, 168-174. https://doi.org/10.1016/j.jcis.2009.03.019

[33] Tang, W.-W., Zeng, G.-M., Gong, J.-L., Liang, J., Xu, P., Zhang, C. and Huang, B.-B. (2014) Impact of Humic/Fulvic Acid on the Removal of Heavy Metals from Aqueous Solutions Using Nanomaterials: A Review. Science of the Total Environment, 468-469, 1014-1027.

[34] Li, L., Qiang, X., Lina, C., Wei, G. and Deyi, W. (2016) Adsorption of Phosphate from Water by Easily Separable $\mathrm{Fe}_{3} \mathrm{O}_{4}$ at $\mathrm{SiO}_{2}$ Core/Shell Magnetic Nanoparticles Functionalized with Hydrous Lanthanum Oxide. Journal of Colloid and Interface Science, 465, 76-82. https://doi.org/10.1016/j.jcis.2015.11.043

[35] Tu, Y.-J., You, C.-F., Chang, C.-K. and Chen, M.-H. (2015) Application of Magnetic Nano-Particles for Phosphorus Removal/Recovery in Aqueous Solution. Journal of the Taiwan Institute of Chemical Engineers, 46, 148-154.

[36] Tombacz, E., Toth, I.Y., Nesztor, D., Illes, E., Hajdu, A., Szekeres, M. and Vekas, L. (2013) Adsorption of Organic Acids on Magnetite Nanoparticles, pH-Dependent Colloidal Stability and Salt Tolerance. Colloids and Surfaces A: Physicochemical and Engineering Aspects, 435, 91-96. https://doi.org/10.1016/j.colsurfa.2013.01.023

[37] Martina, K. and Marcela, P. (2017) Lignitic Humic Acids as Environmentally-Friendly Adsorbent for Heavy Metals. Journal of Chemistry, 2017, Article ID: 7169019.

[38] Patrycja, B., Valeria, D. and Zofia, S. (2016) Effects of Selected Chemical and Physicochemical Properties of Humic Acids from Peat Soils on Their Interaction Mechanisms with Copper Ions at Various pHs. Journal of Geochemical Exploration, 168, 119-126. https://doi.org/10.1016/j.gexplo.2016.06.004

[39] Nicole, D.D., Hongmei, C., Derek, W. and Patrick, G.H. (2016) Potential Origin and Formation for Molecular Components of Humic Acids in Soils. Geochimica et Cosmochimica Acta, 178, 210-222. https://doi.org/10.1016/j.gca.2016.01.013

[40] Bruna, A., Gomes D.M., Fernanda, L.M. and Maria, H.A. (2016) Humic Acids: Structural Properties and Multiple Functionalities for Novel Technological Developments. Materials Science and Engineering, 62, 967-974.

https://doi.org/10.1016/j.msec.2015.12.001 
[41] Soerja, K., Sri, J.S., Dwi, S. and Bambang, R. (2015) Synthesis and Characterizatation of Magnetite Nanoparticle Coated Humic Acid $\left(\mathrm{Fe}_{3} \mathrm{O}_{4} / \mathrm{HA}\right)$. Procedia Environmental Sciences, 30, 103-108.

[42] Luciano, C., Mariano, C., Delia, B., Soria, M., Sergio, M., Peter, R., Ogilby Fernando, S., Garcia, E. and Daniel, O. (2012) Effect of Humic Acid Binding to Magnetite Nanoparticles on the Photogeneration of Reactive Oxygen Species. Separation and Purification Technology, 91, 23-29. https://doi.org/10.1016/j.seppur.2011.08.028

[43] Peng, L., et al. (2012) Modifying $\mathrm{Fe}_{3} \mathrm{O}_{4}$ Nanoparticles with Humic Acid for Removal of Rhodamine B in Water. Journal of Hazardous Materials, 209-210, 193-198.

[44] Jiang, W., et al. (2014) Cr (VI) Adsorption and Reduction by Humic Acid Coated on Magnetite. Environmental Science \& Technology, 48, 8078-8085.

[45] Mamun, R., Nathaniel, T., Price, M., Angel, G.P. and Kevin, E.O. (2017) Effective Removal of Phosphate from Aqueous Solution Using Humic Acid Coated Magnetite Nanoparticles. Water Research, 123, 353-360.

https://doi.org/10.1016/j.watres.2017.06.085

[46] Sophie, L., Delphine, F., Marc, P., Alain, R., Caroline, R., Luce, V.E. and Robert, N.M. (2008) Magnetic Iron Oxide Nanoparticles: Synthesis, Stabilization, Vectorization, Physicochemical Characterizations and Biological Applications. Chemical Reviews, 108, 2064-2110. https://doi.org/10.1021/cr068445e

[47] Schwarzer, H.C. and Peukert, W. (2004) Tailoring Particle Size through Nanoparticle Precipitation. Chemical Engineering Communications, 19, 580-606. https://doi.org/10.1080/00986440490270106

[48] Jolivet, J.P., Chaneac, C. and Tronc, E. (2004) Iron Oxide Chemistry: From Molecular Clusters to Extended Solid Networks. Chemical Communications, 10, 481-487.

[49] Pileni, M.P. and Duxin, N. (2000) Micelle Technology for Magnetic Nanosized Alloys and Composites. Chemical Innovation, 30, 25-33.

[50] Luciano, C., Fernando, S., Garcia, E. and Monica, C. (2013) Applications of Magnetite Nanoparticles for Heavy Metal Removal from Wastewater. 1-10.

[51] Jeongyun, C., Jinwook, C., Wonhee, L. and Jong, K. (2016) Phosphorous Adsorption on Synthesized Magnetite in Wastewater. Journal of Industrial and Engineering Chemistry, 34, 198-203. https://doi.org/10.1016/j.jiec.2015.11.008

[52] Tombacz, E., Horvat, M. and Illes, E. (2006) Magnetite in Aqueous Medium Coating Its Surface and Surface Coated with It. Romanian Reports in Physics, 58, 281-286.

[53] Illes, E. and Tombacz, E. (2004) The Role of Variable Surface Charge and Surface Complexation in the Adsorption of Humic Acid on Magnetite. Colloids and Surfaces, 203, 99-109.

[54] Illes, E. and Tombacz, E. (2006) The Effect of Humic Acids Adsorption on $\mathrm{pH}$-Dependent Surface Charging and Aggregation of Magnetic Nanoparticles. Colloids and Surfaces, 295, 115-123. https://doi.org/10.1016/j.jcis.2005.08.003

[55] Petcharoen, K. and Sirivat, A. (2012) Synthesis and Characterization of Magnetic Nanoparticles via the Chemical Co-Precipitation Method. Materials Science and Engineering, 177, 421-427. https://doi.org/10.1016/j.mseb.2012.01.003

[56] Xie, F., Wu, F., Liu, G., Mu, Y., Feng, C., Wang, H. and Giesy, J.P. (2014) Removal of Phosphate from Eutrophic Lakes through Adsorption by In-Situ Formation of Magnesium Hydroxide from Diatomite. Environmental Science \& Technology, 48, 582-590. https://doi.org/10.1021/es4037379 
[57] Tahir, S.S. and Rauf, N. (2006) Removal of a Cationic Dye from Aqueous Solutions by Adsorption onto Bentonite Clay. Chemosphere, 63, 1842-1848. https://doi.org/10.1016/j.chemosphere.2005.10.033

[58] Yantasee, C.L., Warner, T., Sangvanich, R.S., Addleman, T.G., Carter, R.J., Wiacek, G.E., Fryxell, C. and Timchalk, M.G. (2007) Removal of Heavy Metals from Aqueous Systems with Thiol Functionalized Superparamagnetic Nanoparticles. Environmental Science \& Technology, 41, 5114-5119. https://doi.org/10.1021/es0705238

[59] Liu, J.-F., Zhao, Z.-S. and Jiang, G.-B. (2008) Coating $\mathrm{Fe}_{3} \mathrm{O}_{4}$ Magnetic Nanoparticles with Humic Acid for High Efficient Removal of Heavy Metals in Water. Environmental Science \& Technology, 42, 6949-6954. https://doi.org/10.1021/es800924c

[60] Gucek, A., Bilgen, S. and Mazmanci, M.A. (2005) Adsorption and Kinetic Studies of Cationic and Anionic Dyes on Pyrophyllite from Aqueous Solutions. Journal of Colloid and Interface Science, 286, 53-60. https://doi.org/10.1016/j.jcis.2005.01.012

[61] Yeojoon, Y., Wonkyu, P., Tae-Mun, H., Dae, H.Y. and WooSeok, J.K. (2016) Comparative Evaluation of Magnetite-Graphene Oxide and Magnetite-Reduced Graphene Oxide Composite for As(III) and As(V) Removal. Journal of Hazardous Materials, 304, 196-204. https://doi.org/10.1016/j.jhazmat.2015.10.053

[62] Chen, R., Zhi, C., Yang, H., Bando, Y., Zhang, Z., Sugiur, N. and Golberg, D. (2011) Arsenic (V) Adsorption on $\mathrm{Fe}_{3} \mathrm{O}_{4}$ Nanoparticle-Coated Boron Nitride Nanotubes. Journal of Colloid and Interface Science, 359, 261-268. https://doi.org/10.1016/j.jcis.2011.02.071

[63] Ding, H., Zhao, Y., Duan, Q., Wang, J., Zhang, K., Ding, G., Xie, X. and Ding, C. (2017) Efficient Removal of Phosphate from Aqueous Solution Using Novel Magnetic Nanocomposites with $\mathrm{Fe}_{3} \mathrm{O}_{4} @ \mathrm{SiO}_{2}$ Core and Mesoporous $\mathrm{CeO}_{2}$ Shell. Journal of Rare Earths, 35, 984. https://doi.org/10.1016/S1002-0721(17)61003-2

[64] Singh, S., Barick, K.C. and Bahadur, D. (2011) Surface Engineered Magnetic Nanoparticles for Removal of Toxic Metal Ions and Bacterial Pathogens. Journal of Hazardous Materials, 192, 1539-1547. https://doi.org/10.1016/j.jhazmat.2011.06.074

[65] Liu, J.F., Zhao, Z.S. and Jiang, G.B. (2008) Coating $\mathrm{Fe}_{3} \mathrm{O}_{4}$ Nanoparticle with Humic Acidfor High Efficient Removal of Heavy Metal in Water. Environmental Science and Technology, 42, 6949-6954. https://doi.org/10.1021/es800924c

[66] Badruddoza, A.Z., Tay, A.S., Tan, P.Y., Hidajat, K. and Uddin, M.S. (2011) Carboxymethyl- $\beta$-Cyclodextrin Conjugated Magnetic Nanoparticles as $\mathrm{Na}$ no-Adsorbents for Removal of Copper Ions: Synthesis and Adsorption Studies. Journal of Hazardous Materials, 185, 1177-1186. https://doi.org/10.1016/j.jhazmat.2010.10.029

[67] Goon, I.Y., Zhang, C., Lim, M. and Gooding, J.J. (2010) Controlled Fabrication of Polyethylenimine-Functionalized Magnetic Nanoparticles for the Sequestration and Quantification of Free $\mathrm{Cu}^{2+}$. Langmuir, 26, 12247-12252. https://doi.org/10.1021/la101196r

[68] Chou, C.M. and Lien, H.L. (2011) Dendrimer-Conjugated Magnetic Nanoparticles for Removal of Zinc (II) from Aqueous Solutions. Journal of Nanoparticle Research, 13, 2099-2107. https://doi.org/10.1007/s11051-010-9967-5

[69] Wang, J., Zheng, S., Shao, Y., Liu, J., Xu, Z. and Zhu, D. (2010) Amino-Functionalized $\mathrm{Fe}_{3} \mathrm{O}_{4} @ \mathrm{SiO}_{2}$ Core-Shell Magnetic Nanomaterial as a Novel Adsorbent for Aqueous Heavy Metals Removal. Journal of Colloid and Interface Science, 349, 293-299. https://doi.org/10.1016/j.jcis.2010.05.010

[70] Wu, Y., Zhang, J., Tong, Y. and Xu, X. (2009) Chromium (VI) Reduction in 
Aqueous Solutions by $\mathrm{Fe}_{3} \mathrm{O}_{4}$-Stabilized $\mathrm{Fe}^{0}$ Nanoparticles. Journal of Hazardous Materials, 172, 1640-1645. https://doi.org/10.1016/j.jhazmat.2009.08.045

[71] Cutting, R.S., Coker, V.S., Telling, N.D., Kimber, R.L., Pearce, C.I., Ellis, B.L., Lawson, R.S, Van GerritLaan, D.E.R., Pattrick, R.A.D., Vaughan, D.J., Arenholz, E. and Lloyd, J.R. (2010) Optimizing Cr(VI) and Tc(VII) Remediation through Nanoscale Biomineral Engineering. Environmental Science \& Technology, 44, 2577-2584. https://doi.org/10.1021/es902119u

[72] Wang, Y., Morin, G., Ona-Nguema, G., Juillot, F., Calas, G. and Brown, G.E. (2011) Distinctive Arsenic (V) Trapping Modes by Magnetite Nanoparticles Induced by Different Sorption Processes. Environmental Science \& Technology, 45, 7258-7266. https://doi.org/10.1021/es200299f

[73] Chowdhury, S.R. and Yanful, E.K. (2010) Arsenic and Chromium Removal by Mixed Magnetite-Maghemite Nanoparticles and the Effect of Phosphate on Removal. Journal of Environmental Management, 91, 2238-2247. https://doi.org/10.1016/j.jenvman.2010.06.003

[74] Yang, W., Kan, A.T., Chen, W. and Tomson, M.B. (2010) pH-Dependent Effect of Zinc on Arsenic Adsorption to Magnetite Nanoparticles. Water Research, 44, 5693-5701. https://doi.org/10.1016/j.watres.2010.06.023

[75] Zhang, M., Pan, G., Zhao, D. and He, G. (2011) XAFS Study of Starch-Stabilized Magnetite Nanoparticles and Surface Speciation of Arsenate. Environmental Pollution, 159, 3509-3514. https://doi.org/10.1016/j.envpol.2011.08.017

[76] Murray, B. and Mcbride (1994) Environmental Chemistry of Soils. Oxford University Press, New York, Oxford, 346-352. 